\title{
Influence of Bacillus cereus-Gold Interaction on Bio- flotation of Gold in the Presence of Potassium Butyl Xanthate
}

\author{
Samah El-Sayed ${ }^{1}$, Einas H. El-Shatoury ${ }^{2}$, Nagui A. Abdel-Khalek ${ }^{1}{ }^{\mathbb{D}}$, Ali Abdel-Motelib ${ }^{3}$, Mohamed A. \\ Abdel-Khalek 1(D)

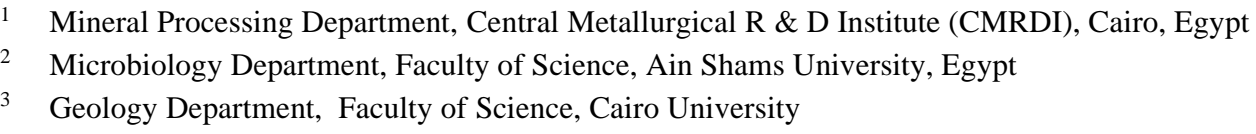

Scopus Author ID 7003523542

Received: 3.01.2021; Revised: 30.01.2021; Accepted: 1.02.2021; Published: 7.02.2021

\begin{abstract}
Bacillus cereus is used to enhance the gold floatability in the presence of potassium butyl xanthate (PBX) as a collector and pine oil as a frother. The effect of bacteria interaction on the gold and quartz behavior as the main components of the gold ore was investigated using zeta-potential, contact angle, SEM, and FTIR measurements. The effect of $\mathrm{pH}$, contact time, temperature, and concentration of xanthate, pine oil, and Bacillus cereus on the floatability of the gold and quartz was investigated. The zeta-potential of gold is strongly affected by Bacillus cereus interaction, while the maximum floatability is achieved at neutral $\mathrm{pH}$. A concentrate of $10612 \mathrm{~g} / \mathrm{t}$ gold with $95 \%$ recovery is obtained from a binary mixture contains $500 \mathrm{~g} / \mathrm{t}$ gold in the presence of $1 \times 10^{8}$ Bacillus cereus cells, $5 \times 10^{-3} \mathrm{M}$ potassium butyl xanthate and $5 \times 10^{-3} \mathrm{M}$ pine oil at $\mathrm{pH} 7$ and $35^{\circ} \mathrm{C}$ for $10 \mathrm{~min}$.
\end{abstract}

Keywords: gold; Bacillus cereus; bio-flotation; potassium butyl xanthate; bio-beneficiation.

(C) 2021 by the authors. This article is an open-access article distributed under the terms and conditions of the Creative Commons Attribution (CC BY) license (https://creativecommons.org/licenses/by/4.0/).

\section{Introduction}

Gold element has special characteristics such as lustrous color and high resistance. It is used in jewelry, electronic circuits, and medical applications due to its unique physical and chemical properties [1]. Gold has been used in the electronic industries due to its higher electrical conductivity and corrosion resistance. Gold occurs in nature as metal or as alloys with other metals. It is usually associated with quartz or pyrite minerals. It is a rare element with a concentration of $0.005 \mathrm{~g} / \mathrm{t}$ of the earth's crust. The low-grade deposits contain 3 and 6 $\mathrm{g} / \mathrm{t}$, so it is challenging to meet the commercial grade $(3000-4000 \mathrm{~g} / \mathrm{t})$. Usually, gold is concentrated in its ores using gravity, flotation, or cyanidation techniques, while refining is carried out by electrolysis [2, 3].

Although the flotation technique is widely applied for the gold enrichment in the goldbearing mineral ores, there is no enough research for the flotation of gold-bearing ores. Flotation is essential to processing the low-grade gold ore and removing the undesired impurities before the next extraction process. It is also used for treating complex gold ores such as refractory and metallic ores. Except for the gravity separation technique, flotation is a costeffective method for gold ore processing. However, gold flotation has many problems depending on the ore's composition $[4,5]$. 
Nowadays, biological processing routes are sought to solve the problems associated with lean grade ores. The traditional methods fail to separate the minerals from complex ores. Bio-beneficiation refers to the selective removal of undesirable mineral constituents from ore by utilizing microorganisms as surface modifiers, depressants, collectors, or dispersing agents to enhance the separation of one mineral from another either by flotation or flocculation [6-8], thus enriching it concerning the desired valuable minerals. Bio-beneficiation processes are relatively new and are under intense investigation in recent years. Most of the studies are so far confined to the laboratory [9-11]. Since the bacteria adhere to a mineral surface within a few minutes and alter the surface properties essential in mineral beneficiation techniques, the microorganisms have numerous applications in the flotation and flocculation processes. The behavior of bacterial cells on the mineral surface is the basis for successfully bio-beneficiation process. The selective bacterial adhesion on the mineral surface is important for selective surface modification, which leads to efficient separation [12].

This work investigates Bacillus cereus's behavior as a surface modifier for gold to enhance its floatability and thus its separation from its synthetic mixture with quartz.

\section{Materials and Methods}

\subsection{Materials}

Two pure gold samples were delivered from "Alfa-Easer" Company, UK. The first sample of less than $0.149 \mathrm{~mm}$ particle size $(99.998 \%)$ was employed in flotation experiments, while the second is less than $0.074 \mathrm{~mm}$ (spherical, 99.9\%) was used for surface behavior investigation. The pure quartz sample of $0.149 \mathrm{~mm}$ particle size was supplied by the Egyptian Mineral Resources Authority (EMRA). Analytical grade $\mathrm{NaOH}, \mathrm{HCl}$, and $\mathrm{HNO}_{3}$ were used in this study. Potassium butyl xanthate (PBX), was used as a flotation collector. All chemicals are supplied by Sigma-Aldrich, Germany. Pure Pine oil of chemical grade is supplied by El-Nasr Chemical Company and Guangzhou chemicals Co., Ltd.Freshly prepared nutrient broth/ agar was used for cultivation of bacterial strains.

\subsection{Methods}

\subsubsection{Bacterial isolation}

Bacillus cereus is isolated, purified by streaking on nutrient agar plates, then transferred to nutrient agar slopes stored at $4{ }^{\circ} \mathrm{C}$ and sub-cultured monthly. The nutrient agar was used for the cultivation of bacterial strains. The counting of the bacterial cells was carried out using a hemocytometer [10].

\subsubsection{Measurements}

A laser Zeta Meter 'Malvern Instruments Model Zeta Sizer NAno ZS' was used for zeta potential measurements. A $0.05 \mathrm{~g}$ of a solid sample is placed in $50 \mathrm{ml} 10^{-2} \mathrm{M} \mathrm{NaCl}$ solution. A definite amount of the bacteria is added, and then it is conditioned for 60 minutes at definite $\mathrm{pH}$. The contact angle measurements for the pure gold and quartz before and after conditioning with different bacteria concentration were carried out using Contact Angle meter Model Drop-Master DM-701 at room temperature $\left(25^{\circ} \mathrm{C}\right)$. All measurements were performed three times and averaged as a confirmed result. 
The morphology and structural formation were determined using a scanning electron microscope (SEM) model JEOLJSM-5400, Japan. For FTIR analysis, the spectrum is obtained with $\mathrm{KBr}$ pellets prepared with solid sample and analytical grade $\mathrm{KBr}$ from Merck. The FTIR spectrum was obtained with a Spectrum 2000 Perkin Elmer spectrometer of 4000 and $400 \mathrm{~cm}^{-1}$ range.

The gold was determined in the binary mixture and concentrates using "Rigaku super Mini 200" X-ray fluorescence. The sample was pressed into a pellet by mixing the sample with Boreox BM-0008 binder, and the mixture was subjected to 20-ton press using "Fluxana PR$25 \mathrm{~N}$ " for $20 \mathrm{Sec}$.

\subsubsection{Flotation experiments}

A bench-scale flotation experiment was carried out using a flotation column with 100 $\mathrm{ml}$ capacity. One gram of solid was conditioned using definite conditions of $\mathrm{pH}$, bacterial concentration/PBX, and conditioning time. The flotation was conducted for 5 minutes at an air follow the rate of $0.65 \mathrm{~cm}^{3} / \mathrm{min}$. Both floated and sank fractions were collected, dried, weighted, and chemically analyzed. All flotation experiments, whether pure gold and quartz or their mixture, were carried out three times and averaged as a confirmed result.

\section{Results and Discussion}

\subsection{Surface characteristic of pure gold and quartz}

\subsubsection{Zeta potential and contact angle}

Fig. 1. shows that the isoelectric point for quartz is located at $\mathrm{pH} 2.1$. The quartz as an oxide mineral forms a hydroxylated surface when it is in contact with water vapor. The adsorption of $\mathrm{H}^{+}$onto the hydroxylated quartz surface compresses the diffuse electrical double layer. Therefore, the zeta potential of quartz becomes more positive. On the contrary, OH's adsorption onto the hydroxylated surface would increase the thickness of the diffuse electrical double layer [13]. The gold particles have a negative charge at all $\mathrm{pH}$ range. The Zeta potential of the gold depends on $\mathrm{pH}$, indicating that both $\mathrm{H}^{+}$and $\mathrm{OH}^{-}$are potentially determining ions. The results showed that the electronegativity of zeta potential increases gradually with increasing the $\mathrm{pH}$. The IEP of the gold was not determined. It was reported that the isoelectric point of gold in chloride media is around $\mathrm{pH} 2$ and suggested that the $\mathrm{OH}^{-}$ions are adsorbed at the inert surface [14].

Bacillus cereus is positively charged at $\mathrm{pH} 2$ with an isoelectric point at $\mathrm{pH} 2.25$, which agrees with the reported IEP of 2.5. The zeta potential of bacterial isolates alone was performed. It explained that the bacterial cell charge originates from dissociation or protonation of carboxyl and amino groups and consequently depends on $\mathrm{pH}$. At higher $\mathrm{pH}$, it becomes progressively negatively charged due to proton dissociation [15].

The gold surface is strongly affected due to bacterial interaction, and its IEP became 2.1 rather than 1.5. On the other hand, there is no significant change in quartz minerals' zeta potential after treatment. Although both bacteria and the mineral surfaces are negatively charged, the adhesion is based on the bacteria's surface heterogeneity with a polysaccharide envelope. It also includes hydroxyl, hydrophobic and ionic moieties. The flexible fimbriae regulate the surface charge. The dissolving ions from the mineral alter the bacteria's surface 
charge to reduce repulsion [6]. The hydrogen bonding and chemical interaction also play significant roles in bacterial interaction with single minerals [16].

The contact angle characterizes the surface properties related to the flotation. The greater the contact angle, the greater is the work of adhesion between the particle and bubble, and the more resilient the system is against disruptive forces [17]. Fig. 2 shows the contact angle of the gold and quartz before and after treatment with Bacillus cereus. The contact angle of quartz surface is decreased from $28.9^{\circ}$ to $9.6^{\circ}$ with increasing bacteria concentration up to $5 \times 10^{6}$ cells $/ \mathrm{ml}$. The contact angle of gold is slightly decreased with increasing bacteria concentration.
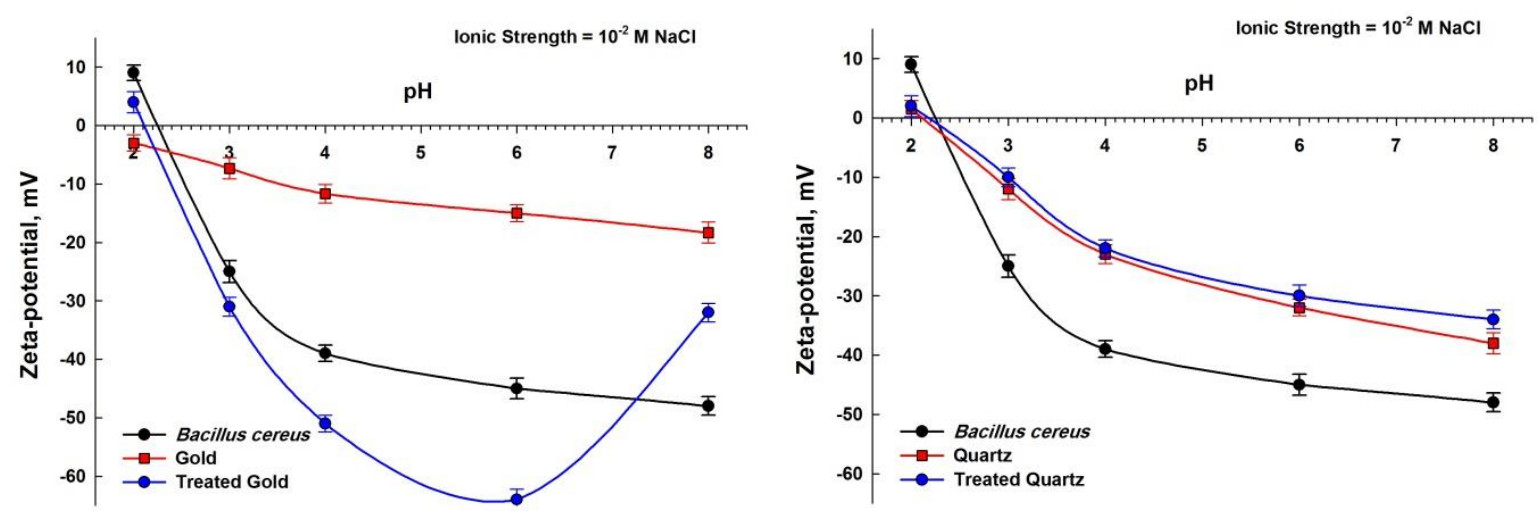

Figure 1. Zeta potential of pure gold and quartz and their treated forms with Bacillus cereus.

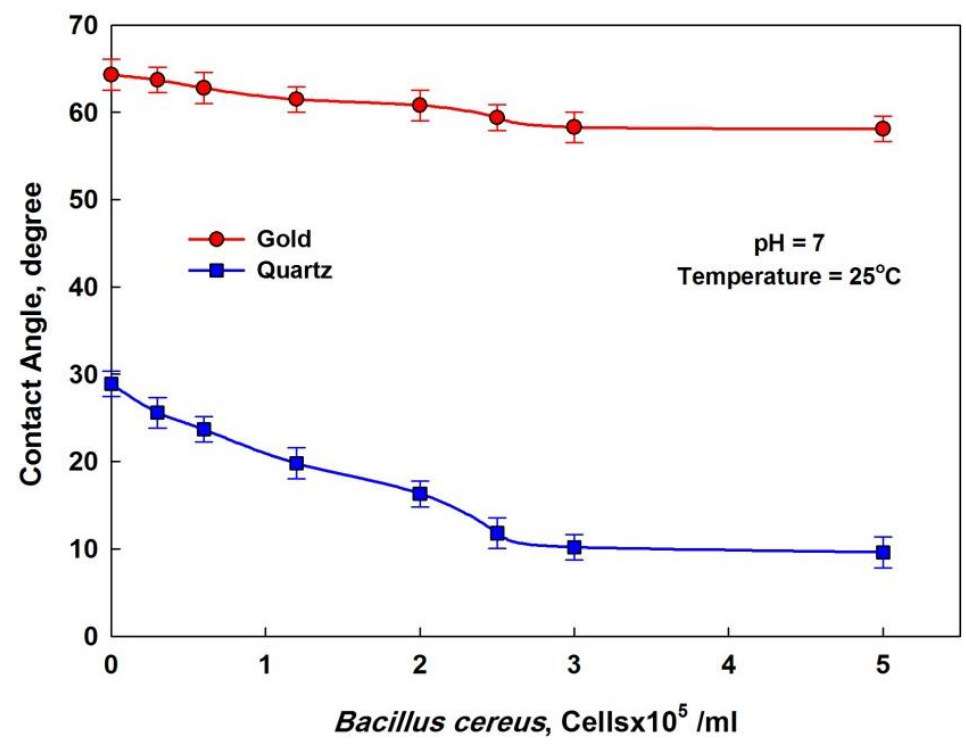

Figure 2. Contact angle of pure gold and quartz and their treated forms with Bacillus cereus.

\subsubsection{FTIR of gold, quartz, and Bacillus cereus}

The FTIR of bacteria usually includes the $\mathrm{O}-\mathrm{H}, \mathrm{C}-\mathrm{C}, \mathrm{CH}_{2}, \mathrm{C}-\mathrm{O}, \mathrm{C}-\mathrm{N}$, and $\mathrm{C}=\mathrm{O}$ bands for polysaccharides and lipids (protein) [18]. The main characteristic peaks for Bacillus cereus are located in the range from $425-874 \mathrm{~cm}^{-1}$ and $1637 \mathrm{~cm}^{-1}$ which belongs to $\mathrm{C}=\mathrm{O}$ of amide group and of $\mathrm{O}-\mathrm{C}=\mathrm{O}$ carboxylic groups, $2075 \mathrm{~cm}^{-1}$ for stretch $\mathrm{C}-\mathrm{H}, \mathrm{C}-\mathrm{H}_{2}$ and $\mathrm{C}-\mathrm{H}_{3}$ of alkyl groups, with stretching vibration bands of $\mathrm{O}-\mathrm{H}$ and $\mathrm{N}-\mathrm{H}$ at $2823-3719 \mathrm{~cm}^{-1}$, Fig.3 [19].

FTIR of the pure quartz exhibited the characteristic bands associated with quartz crystals in 400-1200 $\mathrm{cm}^{-1}$, Fig. 3A. It includes the peak at $695 \mathrm{~cm}^{-1}$, which is due to the octahedral site bending symmetry of $\mathrm{Si}-\mathrm{O}$ vibration group. It is characteristic of crystalline quartz. The tetrahedral silicate ion vibrations band is located at around $784 \mathrm{~cm}^{-1}$. The bands around $1080 \mathrm{~cm}^{-1}$ are due to the silicon-oxygen stretching vibrations. The absorption bands 
located at $440-650 \mathrm{~cm}^{-1}$ and $1885 \mathrm{~cm}^{-1}$ involve atomic motions within the $\mathrm{SiO}_{4}$ tetrahedra. As a result of Bacillus cereus interaction, there is no significant change in the quartz spectrum. It is believed that there is no interaction between Bacillus cereus and the quartz surface [20].

The FTIR spectrum of the pure gold includes a broad band at $3486-3668 \mathrm{~cm}^{-1}$ due to stretching of $\mathrm{O}-\mathrm{H}$ which may be adsorbed on the gold surface. The spectrum of the treated gold with Bacillus cereus showed new functional groups, Fig. 3B. The bands are located at $1076,1247,1383,1532$ and $1648 \mathrm{~cm}^{-1}$ which belongs to $\mathrm{C}=\mathrm{O}$ of the amide group and $\mathrm{O}-\mathrm{C}=\mathrm{O}$ of the carboxylic group. Also, stretch vibration band of $\mathrm{O}-\mathrm{H}$ and $\mathrm{N}-\mathrm{H}$ at $3417-3441 \mathrm{~cm}^{-1}$ and $3794 \mathrm{~cm}^{-1}$. The stretching peak of $\mathrm{C}-\mathrm{H}, \mathrm{C}-\mathrm{H}_{2}$, and $\mathrm{C}-\mathrm{H}_{3}$ of alkyl groups are shifted to 2853 $2922 \mathrm{~cm}^{-1}$ [21]. It indicated the role of hydrogen bonding and chemical interaction. Result in significant surface chemical changes, not only on the cell surfaces but also on the gold [22]. It also proved that the type of adsorption that occurred is mainly chemical adsorption, making the gold surface more hydrophobic than that of the quartz.
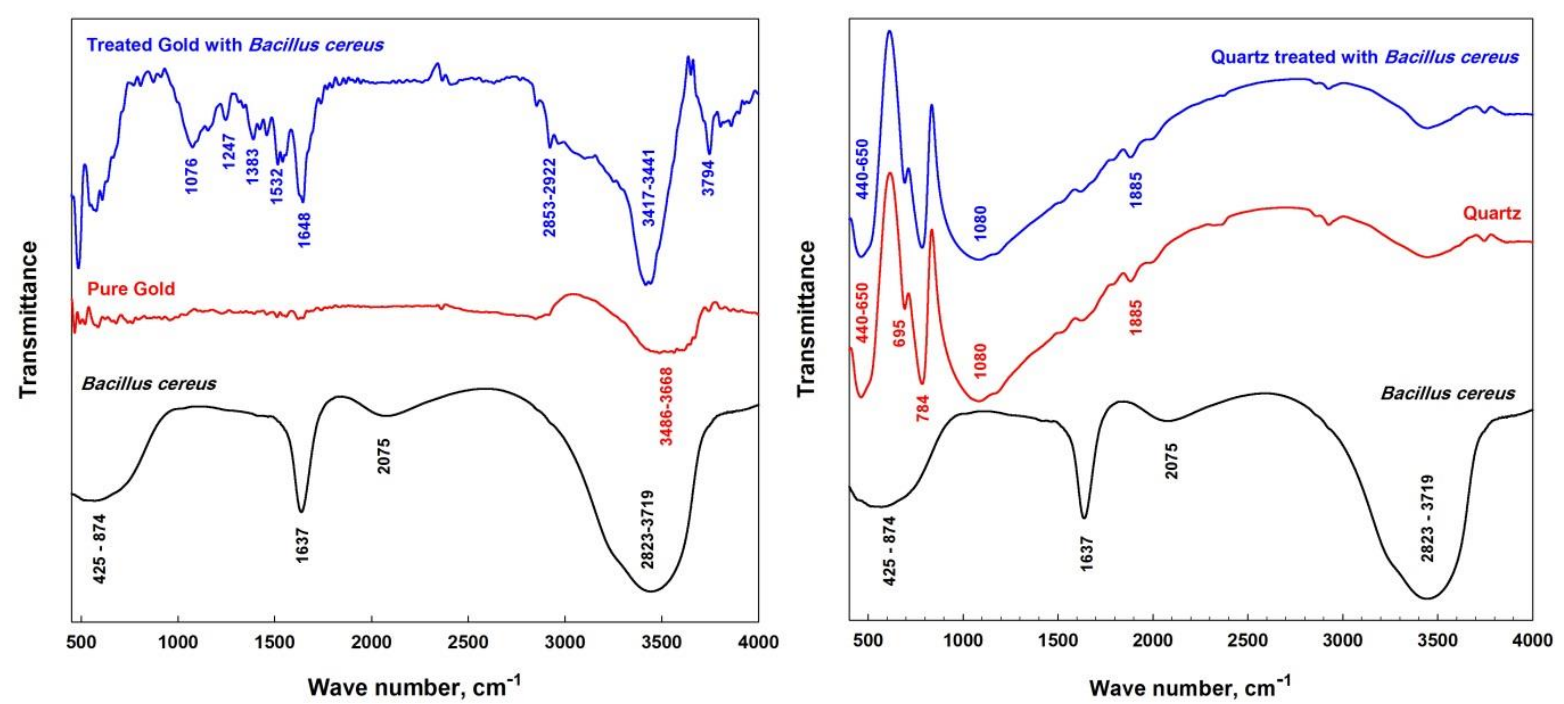

Figure 3. FTIR spectra of pure gold and quartz and their treated forms with Bacillus cereus.

\subsubsection{SEM images of gold, quartz, and Bacillus cereus}

Fig. 4 shows the Scanning Electron Microscope images for the pure quartz (A) and its treated form with Bacillus cereus (B). It is clear that there is no detected Bacillus cereus on the quartz surface. However, there is no significant change in the quartz surface after interaction with Bacillus cereus. On the other hand, Fig. 5 shows significant adsorption of Bacillus cereus on the gold surface. The gold surface is covered with condensed bio-film of both bacterial cells and biological metabolite. The results also showed the presence of nitrogen, oxygen, and carbon elements on the gold surface. This is due to the biofilm formation of bacteria onto the gold surface. It is proved the significant change in gold surface behavior, such as in the zetapotential measurements and thus its floatability [23]. 

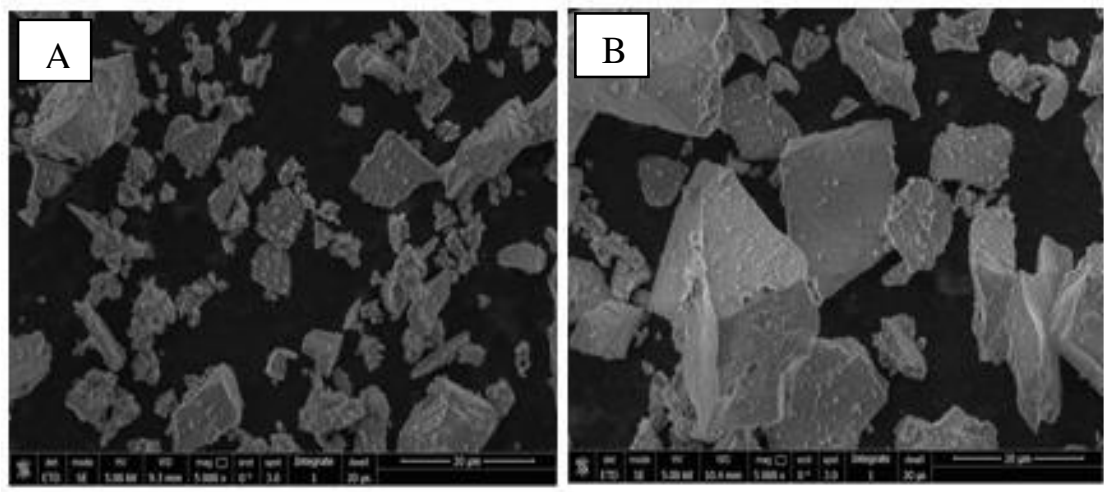

Figure 4. SEM images of pure quartz (A) and after treatment with Bacillus cereus (B).
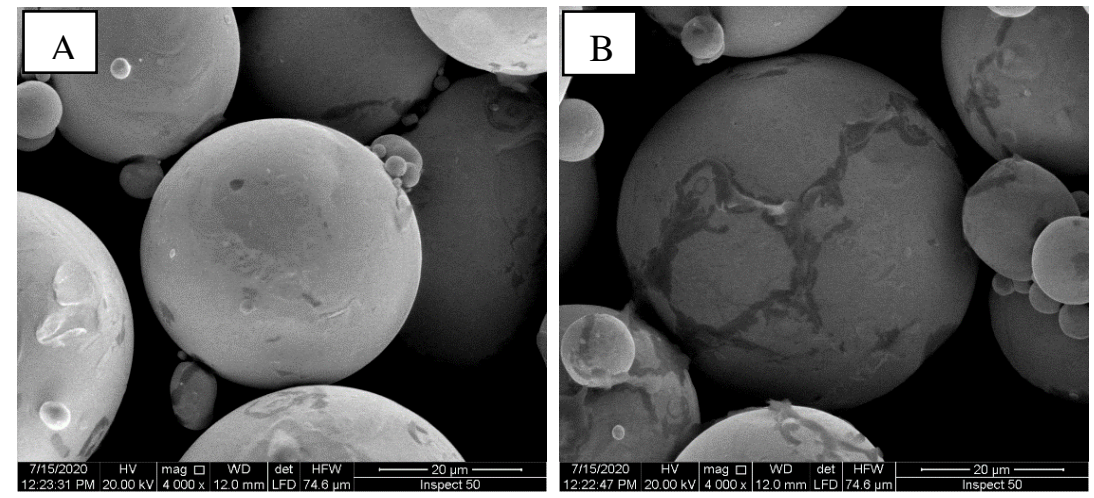

Figure 5. SEM images of pure gold (A) and after treatment with Bacillus cereus (B).

\subsection{Floatability of pure gold and quartz}

\subsubsection{Effect of pine oil}

It was reported that the gold exhibited 53\% floatability while quartz cannot be float without any flotation reagents [24]. Pine oil was used as a frother in this study. Fig. 5 shows the floatability of pure gold metal and quartz minerals as a pine oil concentration function at $\mathrm{pH}$ 7. The pine oil increases the floatability of both gold and quartz due to its oleophilic character. Although the gold is naturally floating, pine oil enhanced its floatability to reach complete flotation at $10^{-2} \mathrm{M}$ of pine oil. Increasing gold recovery as the concentration of pine oil increased due to the increase of bubble production. On the other hand, quartz is not floating. Increasing the pine oil leads the excess bubble formation; hence hydrophilic quartz particles are lifted with a gas bubble [24]. The quartz is floated to reach $89.5 \%$ at $8 \times 10^{-2} \mathrm{M}$ pine oil. The maximum floatability difference $(\approx 84 \%)$ is achieved at $5 \times 10^{-3} \mathrm{M}$ pine oil.

\subsubsection{Effect of potassium butyl xanthate}

Fig. 6. shows the floatability of pure gold and quartz as a function of potassium butyl xanthate (PBX) concentration as a selective collector in the presence of $1 \times 10^{-3} \mathrm{M}$ pine oil. It is stated that the xanthates are absorbed on the surface of the minerals due to chemical reactions between the polar group and the surface, strongly hydrophobic insoluble metal xanthates being formed [25]. The floatability of quartz is slightly increased up to $11.6 \%$ at $8 \times 10^{-2} \mathrm{M}$ then it is decreased to $7.8 \%$. The maximum floatability difference $(\approx 85 \%)$ is achieved at $5 \times 10^{-3} \mathrm{M} \mathrm{PBX}$.

Floatability of gold metal increases as PBX concentration increases to $95.9 \%$ at $0.01 \mathrm{M}$ PBX then decreased to $84.5 \%$ at $0.05 \mathrm{M}$ PBX. The flotation recovery is increased as the PBX 
concentration increases because the PBX acts as a surfactant that increases the hydrophobic characteristic of the solid particles. The xanthate is chemisorbed on the gold surface at a potential which the xanthate can oxidize to dixanthogen as follow: [26]

$$
\begin{gathered}
\text { ROCS }_{2}^{-} \rightleftharpoons\left(\mathrm{ROCS}_{2}\right) \text { ads. }+\mathrm{e}^{-} \\
2 \mathrm{ROCS}_{2} \text { ads. } \rightleftharpoons\left(\mathrm{ROCS}_{2}\right)_{2}
\end{gathered}
$$

Where $\mathrm{R}$ denotes an alkyl chain.

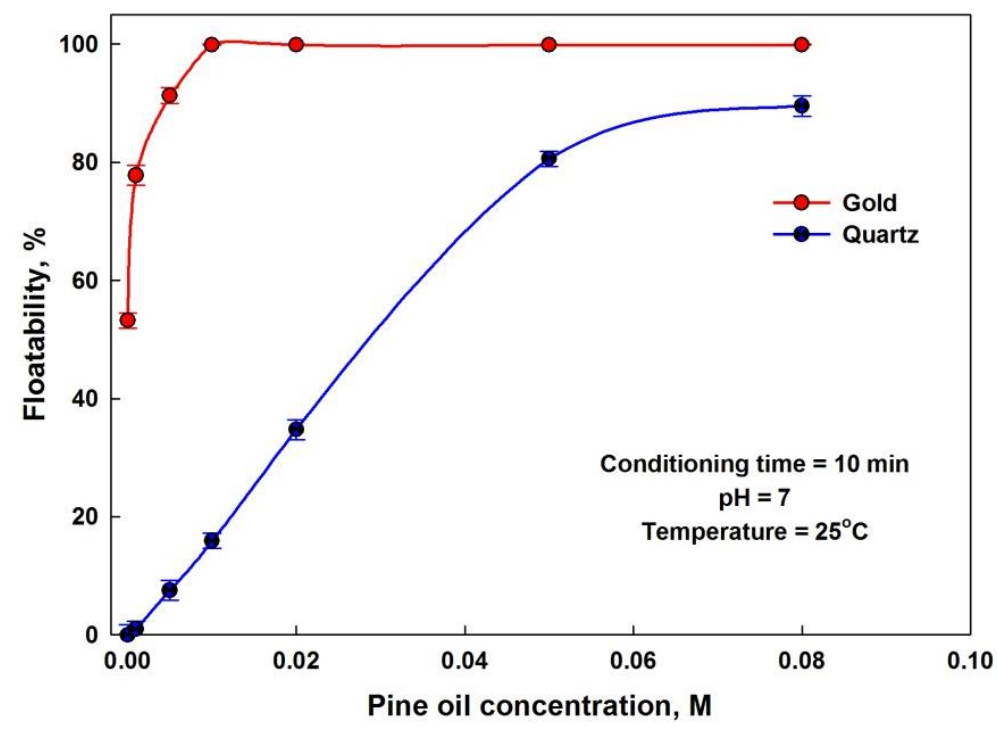

Figure 5. Effect of pine oil concentration on the floatability of pure gold and quartz particles.

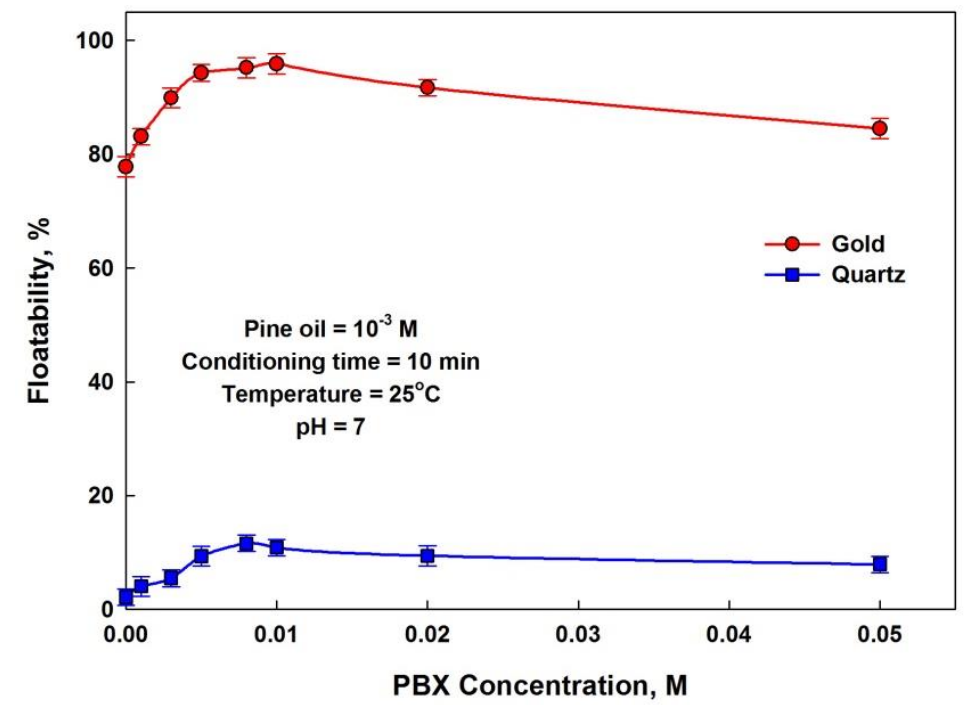

Figure 6. Effect of potassium butyl xanthate concentration on the floatability of pure gold and quartz particles.

\subsubsection{Effect of Bacillus cereus}

Fig. 7 shows the effect of Bacillus cereus concentration (cell count) on the floatability of pure gold and quartz in the presence of $1 \times 10^{-3} \mathrm{M}$ pine oil at $\mathrm{pH}$ 7. Bacillus cereus increases the floatability of both gold and quartz. The gold presented its higher floatability $(\approx 99 \%)$ in the presence of low bacterial concentration $\left(1.5 \times 10^{8}\right.$ cells $)$, while quartz showed its maximum floatability $(\approx 99 \%)$ at a higher bacteria concentration $\left(3.75 \times 10^{8}\right.$ cells $)$. The maximum floatability difference $(\approx 84 \%)$ is achieved in the presence of $1 \times 10^{8}$ bacteria cells. At which the floatability of gold is $94 \%$, while it is only $9.7 \%$ for quartz. These results agree with zeta potential, contact angle, FTIR, and SEM measurements, which showed the adsorption of 
bacteria on the gold surface and the strong effect of bacterial interaction with gold. It is suggested that the attachment and agglomeration of bacterial cells to solid surfaces provide a stable growth environment for the cells and enhances catalytic functions through the localization of cells into biofilms. The excretion of an extracellular polymeric substance composed of macromolecules as polysaccharides, proteins, and lipids promotes biofilms' development on mineral surfaces. It is suggested that a Hydrogen bond is formed between bacteria and mineral surface as a result of the presence of $\left(\mathrm{OH}^{-}\right)$groups of polysaccharide of metabolite. The charge and spacing between them control the biomolecules' interaction with the solid surfaces [27].

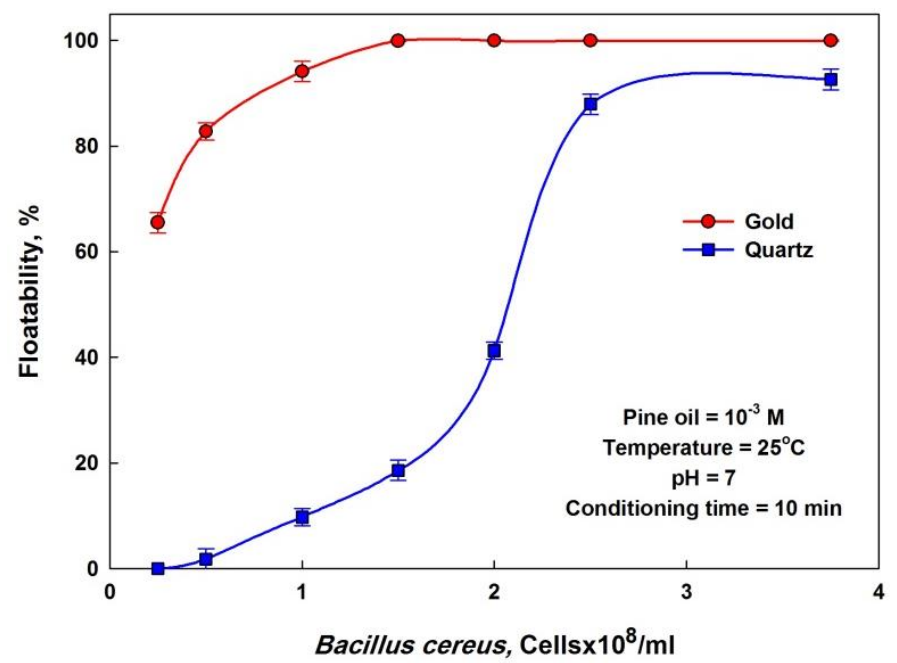

Figure 7. Effect of Bacillus cereus concentration on the floatability of pure gold and quartz particles.

\subsubsection{The dual effect of Bacillus cereus and potassium butyl xanthate}

The floatability of gold and quartz in the presence of $5 \times 10^{-3} \mathrm{M}$ potassium butyl xanthate and $1 \times 10^{-3} \mathrm{M}$ pine oil as a function of Bacillus cereus concentration is presented in Fig. 8. For conditioning with xanthate followed by Bacillus cereus, the floatability of gold and quartz increases with increasing bacteria concentration. The maximum floatability difference $(\approx 85$ $\%)$ is achieved in the presence of $1 \times 10^{8}$ of bacteria cells. At which the floatability of gold is about $91 \%$ while it is only $6 \%$ for quartz.

Although the floatability of gold and quartz by conditioning with xanthate first is more than that of conditioning with Bacillus cereus first, the separation efficiency is better. This is due to the higher amount of floating quartz. Thus, the maximum floatability difference $(\approx 89$ $\%)$ is achieved in the case of conditioning with Bacillus cereus first in the presence of $1 \times 10^{8}$ of bacteria cells. The floatability of gold is about $94 \%$, while it is only $4 \%$ for quartz.

The conditioning with Bacillus cereus prior to xanthate may enhance the xanthate-gold adsorption while it decreases xanthate-quartz adsorption. The exopolymers, or metabolites, interact with the organism and the minerals in a variety of ways. The metabolites of Bacillus cereus, such as the polysaccharides, proteins, and organic acids, are responsible for the surface modification.

The metabolites may form a type of polymeric bridge in potassium butyl xanthate, leading to higher surface modification. Many of the interacting mechanisms are still unknown and need to explain how the bacteria adhere to the solid surface. This is confirmed by the different results for the mode of addition, the bacteria first or the xanthate first [28]. 

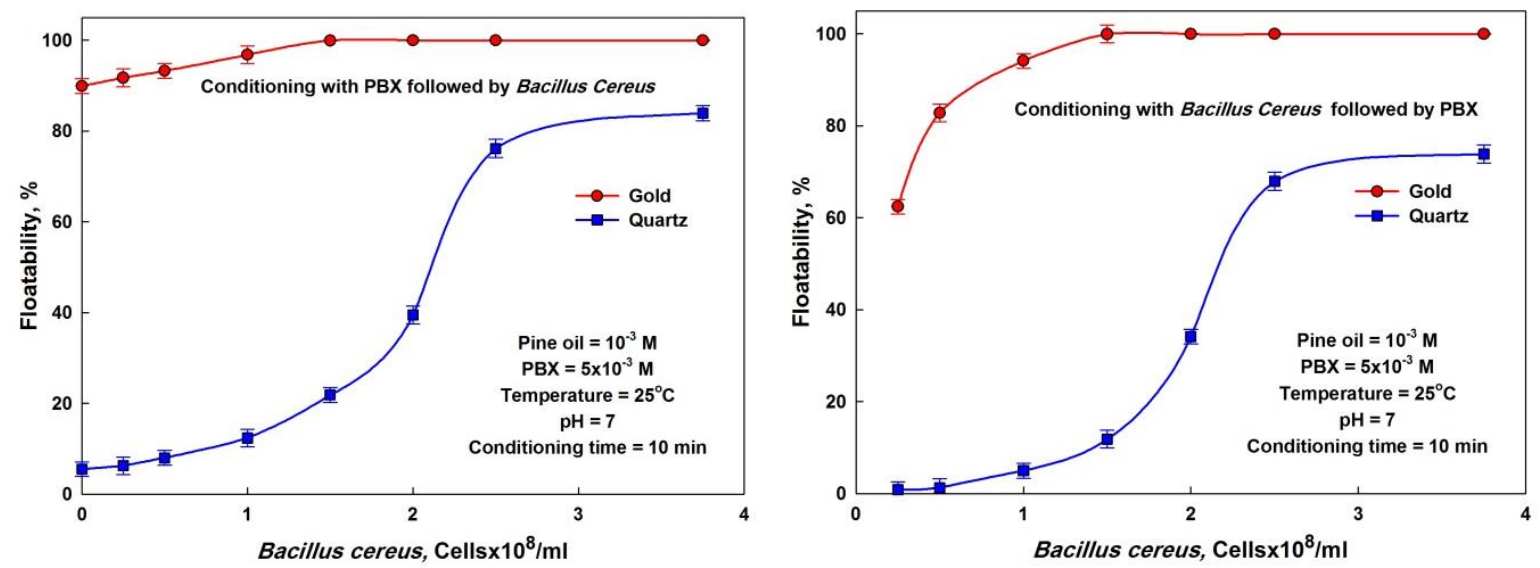

Figure 8. Floatability of pure quartz and gold particles in the presence of Bacillus cereus and potassium butyl xanthate.

\subsection{Binary mixture bio-flotation}

The flotation study of binary mixture aims to determine the effect of interaction between gold and quartz, which may be occurred during their conditioning together rather than individual conditioning. A synthetic binary mixture composed of $0.05 \%$ of pure gold $(500 \mathrm{~g} / \mathrm{t})$ with quartz was employed for this investigation.

\subsubsection{Effect of Bacillus cereus}

The effect of Bacillus cereus concentration (cell count) on the gold grade (g/t) and recovery, in the presence of $5 \times 10^{-3} \mathrm{M}$ potassium butyl xanthate and $5 \times 10^{-3} \mathrm{M}$ pine oil at $25^{\circ} \mathrm{C}$ and $\mathrm{pH} 7$ showed that the gold grade is $9863 \mathrm{~g} / \mathrm{t}$ in the presence of $1 \times 10^{8}$ bacteria cells, Fig. 9. Then it is dramatically decreased to $758 \mathrm{~g} / \mathrm{t}$ in the presence of $3.75 \times 10^{8}$ bacteria cells. On the other hand, the recovery is increased from 39.4 to $80 \%$ in the presence of $1 \times 10^{8}$ bacteria cells. Then it is slightly increased up to $88 \%$ in the presence of $3.75 \times 10^{8}$ bacteria cells. Although the maximum grade $(9863 \mathrm{~g} / \mathrm{t})$ with $39.4 \%$ recovery is achieved at $5 \times 10^{7}$ bacteria cells, $1 \times 108$ bacterial cells are considered the best result at which the grade was $8324 \mathrm{~g} / \mathrm{t}$ with $80 \%$ recovery. As mentioned above, the adsorption of bacteria on the gold enhanced its flotation, which provides a more hydrophobic surface and stable agglomeration [28].

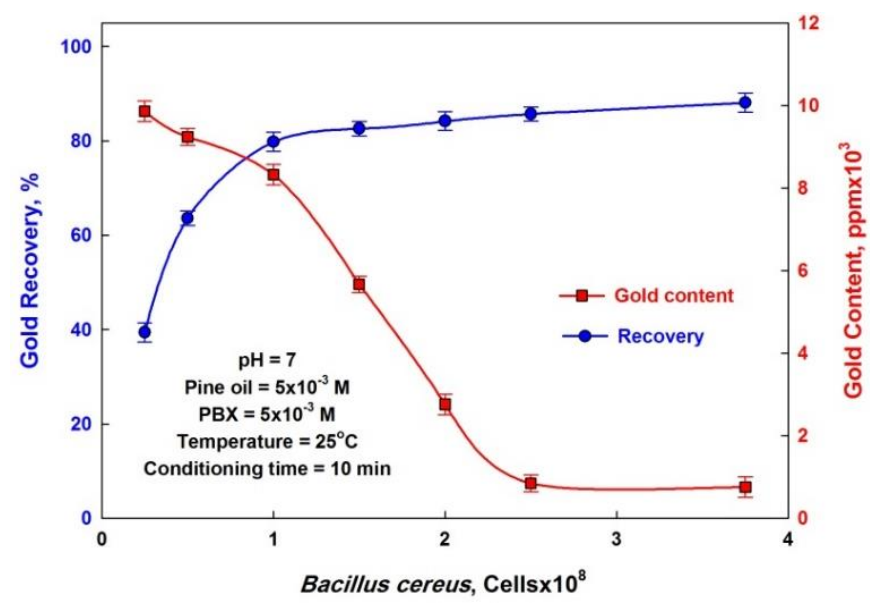

Figure 9. Effect of Bacillus cereus concentration on the gold content and recovery of the floated fraction from the binary mixture.

\subsubsection{Effect of $\mathrm{pH}$}


Neutral $\mathrm{pH}$ is more commonly used for native gold recovery. Native gold shows its maximum floatability in the water at $\mathrm{pH}=6-9$. The floatability is totally inhibited at $\mathrm{pH}>10$. The effect of $\mathrm{pH}$ on the grade and recovery of gold in the presence of bacteria, potassium butyl xanthate, and pine oil showed that the gold grade is increased from 7435 to $10442 \mathrm{~g} / \mathrm{t}$ with increasing the $\mathrm{pH}$ from 5 to 7 , Fig. 10. Then it is dramatically decreased to $2147 \mathrm{~g} / \mathrm{t}$ at $\mathrm{pH} 9$. On the other hand, the recovery is increased from 46.1 to $90.2 \%$ at $\mathrm{pH} 7-8$, and then it is decreased to $39.5 \%$ at $\mathrm{pH} 9$. It was reported that the uncharged and water-insoluble collectors are the most effective collectors for the gold flotation at the natural $\mathrm{pH}$. The xanthates are normally used in slightly alkaline pulps since they decompose in an acid medium and in a very alkaline environment. The hydroxyl ions $\left(\mathrm{OH}^{-}\right)$can displace the xanthate ions from the surface of the mineral [29].

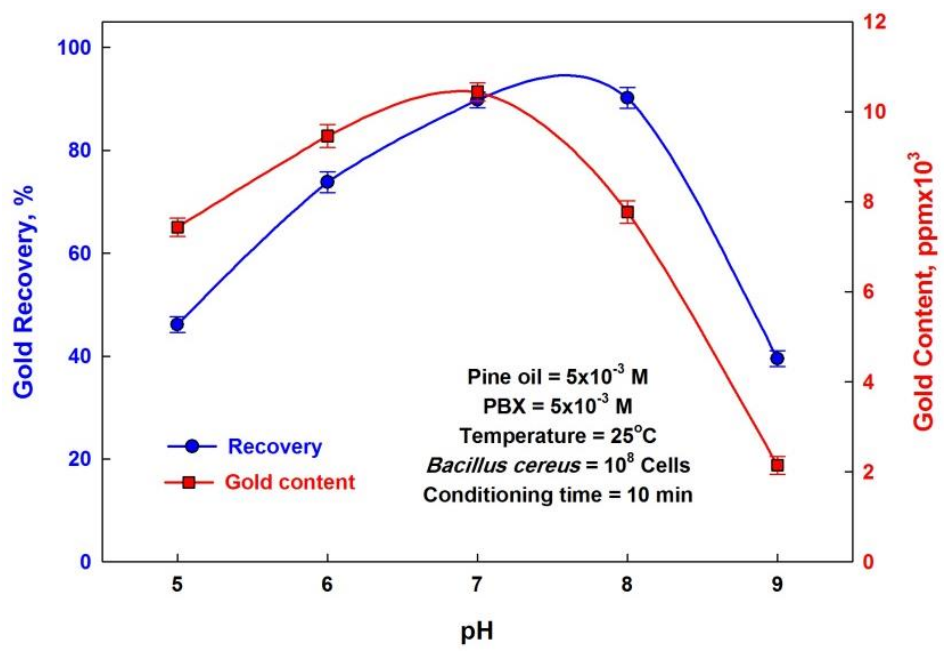

Figure 10. Effect of $\mathrm{pH}$ on the gold content and recovery of the floated fraction from the binary mixture.

\subsubsection{Effect of conditioning time}

The effect of conditioning time on the gold grade and recovery in the presence of bacteria cells, potassium butyl xanthate, and pine oil at $25^{\circ} \mathrm{C}$ and $\mathrm{pH} 7$ is investigated. Fig. 11 shows that the gold grade is increased from 7342 to $10442 \mathrm{~g} / \mathrm{t}$ with increasing conditioning time from 5 to $10 \mathrm{~min}$, and then it is decreased again to $3292 \mathrm{~g} / \mathrm{t}$ after $15 \mathrm{~min}$. On the other hand, the recovery is increased from about 28 to $90 \%$ by increasing the conditioning time from 5 to $10 \mathrm{~min}$. Then it is slightly increased to $94 \%$ after $15 \mathrm{~min}$. This is because the attachment of the particle with the air bubble needs time (induction time). Induction time is associated with the thin water film's properties that separate the particle and bubble just before attaching. For a hydrophobic surface, induction time is short, a few milliseconds. Suppose it is less than the time the particle and bubble are in contact. In that case, attachment is successful, and the particle is floated. The induction time is very large for hydrophobic particles. The hydrophobicity of gold depends on the time due to its higher Hamaker constant $\left(45 \times 10^{-20} \mathrm{~J}\right)$. It results from strong water dispersion forces, whereas its hydrophobicity develops upon physical adsorption of water vapor [17]. 


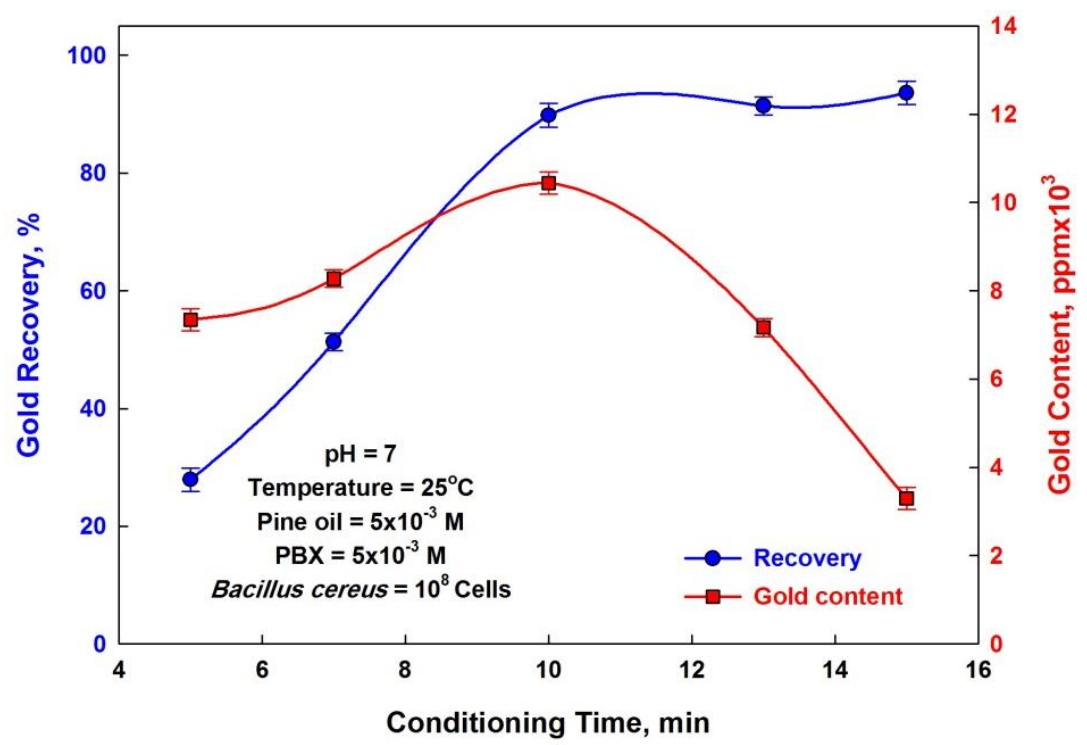

Figure 11. Effect of conditioning time on the gold content and recovery of the floated fraction from the binary mixture.

\subsubsection{Effect of temperature}

The metabolism of bacteria is directly associated with enzymes' presence, which means that the biofilm formation depends on the enzymes' reaction rates. A pivotal factor that affects the enzymatic reaction rate is the temperature, as it is correlated to the formation of cells forming a biofilm [30]. The effect of temperature on both grade and recovery of gold in the presence of bacteria cells, potassium butyl xanthate, and pine oil at $\mathrm{pH} 7$ is investigated. Fig. 12 shows that the gold grade increases from 9194 to $10612 \mathrm{~g} / \mathrm{t}$, increasing temperature from 20 to $35^{\circ} \mathrm{C}$. Then it is decreased again to $7706 \mathrm{~g} / \mathrm{t}$ at $40^{\circ} \mathrm{C}$. On the other hand, the recovery is increased from 63 to $95 \%$ with increasing temperature from 20 to $35^{\circ} \mathrm{C}$, and then it is decreased to $71 \%$ at $40^{\circ} \mathrm{C}$. This is due to the microbial activity usually increases with increasing temperature. The higher the effect of bacteria may be due to increasing the biofilm thickness at $35^{\circ} \mathrm{C}$ compared with that at $20^{\circ} \mathrm{C}$. It is ascribed to the number of appendages. It may also be due increase in the surface area and the likelihood of bacterial adhesion at $35^{\circ} \mathrm{C}$ [31-32]. The high temperature has little impact on removing the biofilm, so the biofilm adherent to the surface increases [34].

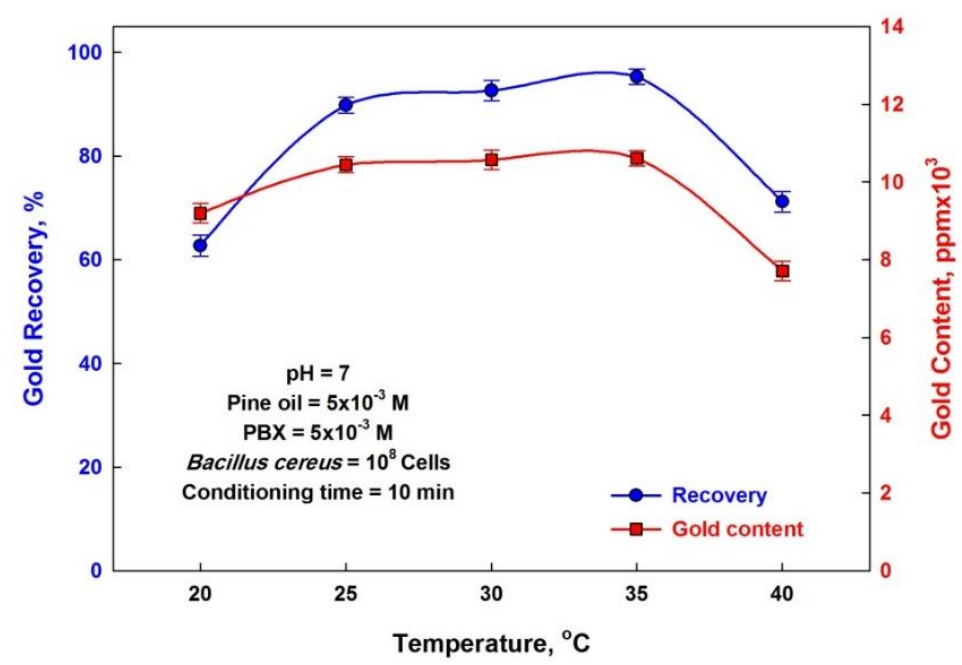

Figure 12. Effect of temperature on the gold content and recovery of the floated fraction from the binary mixture. 


\section{Conclusions}

Bacillus cereus is used as a surface modifier to enhance the flotation selectivity of gold. The gold surface is strongly affected as a result of bacterial interaction, while the quartz doesn't affect it. The gold surface is strongly affected by bacterial interaction, while there is no significant change of the zeta potential of quartz minerals after treatment. FTIR and SEM proved the selective adhesion of Bacillus cereus on the gold surface.

The maximum floatability of pure gold metal and quartz individually after treatment with Bacillus cereus is achieved at $\mathrm{pH} 7-8$ for the gold and $\mathrm{pH} 7$ for quartz. The maximum floatability is achieved after 10 min conditioning time at $35^{\circ} \mathrm{C}$ and $\mathrm{pH} 7$.

The gold flotation from a binary mixture $(500 \mathrm{~g} / \mathrm{t}$ gold $)$ produced a concentrate of 10612 $\mathrm{g} / \mathrm{t}$ gold with $95 \%$ recovery in the presence of $1 \times 10^{8}$ bacteria cells, $5 \times 10^{-3} \mathrm{M}$ potassium butyl xanthate and $5 \times 10^{-3} \mathrm{M}$ pine oil at $35^{\circ} \mathrm{C}$ and $\mathrm{pH} 7$ for $10 \mathrm{~min}$.

\section{Funding}

This research received no external funding.

\section{Acknowledgments}

This research has no acknowledgment.

\section{Conflicts of Interest}

The authors declare no conflict of interest.

\section{References}

1. Pourdasht, M. Study on the surface features of Preg-Robbing carbonaceous matter during oxidation treatment. Electronic Thesis and Dissertation Repository 2018.

2. Habashi, F. Chapter 1-Gold: An Historical Introduction. In: Gold Ore Processing. $2^{\text {nd }}$ Ed. Adams, M.D. Fugue Pte Ltd., Singapore, Elsevier 2016; pp. 1-20, https://doi.org/10.1016/B978-0-444-63658-4.00001-3.

3. Abdel-Khalek, N.; El-Shatoury, E.; Abdel-Motelib, A.; Hassan, M.; Abdel Khalek, M.; El-sayed, S. Mineralogical study and enhanced gravity separation of gold-bearing mineral, South Eastern Desert, Egypt. Physicochemical Problems of Mineral Processing 2020, 56, 839-848, https://doi.org/10.37190/ ppmp/125977.

4. Alfonso, P.; Anticoi, H.; Yubero, T.; Bascompta, M.; Henao, L.; Garcia-Valles, M.; Palacios, S.; Yáñez, J. The Importance of Mineralogical Knowledge in the Sustainability of Artisanal Gold Mining: A Mid-South Peru Case. Minerals 2019, 9, https://doi.org/10.3390/min9060345.

5. Hartmann, R.; Serna-Guerrero, R. A Study on the Electric Surface Potential and Hydrophobicity of Quartz Particles in the Presence of Hexyl Amine Cellulose Nanocrystals and Their Correlation to Flotation. Frontiers in Materials 2020, 7, 1-11, https://doi.org/10.3389/fmats.2020.00053.

6. Azizi, D.; Larachi, F.; Garnier, A.; Lagüe, P.; Levasseur, B. Sorption of aqueous amino acid species on sulphidic mineral surfaces-DFT study and insights on biosourced-reagent mineral flotation. The Canadian Journal of Chemical Engineering 2020, 1-22, https://doi.org/10.1002/cjce.23841.

7. Leontev, A.; Bar-On, R.; Bass, M.; Jurić, M.; Schmetz, C.; Freger, V. Spatial pattern and surface-specificity of particle and microorganism deposition and attachment: Modeling, analytic solution and experimental test. Journal of Colloid and Interface Science 2021, 584, 45-56, https://doi.org/10.1016/ j.jcis.2020.09.098.

8. Kuyumcu, H.Z.; Vilinska, T.B.; Rao, K.H. Biocoagulation and its Application Potentials for Mineral Bioprocessing. The Open Mineral Processing Journal, 2009; 2, 1-11; https://doi.org/10.2174/ 1874841400902010001.

9. Kuyumcu, H.Z.; Pinka, J.; Bielig, T. Investigations on the sorting of very fine particles by Biocoagulation, in Biohydrometallurgy: From single cell to the environment. Advanced material research. Schippers, A.; Sand, W.; Glombitza, F.; Willscher, S. (Eds.). Stafa-Zurich: Trans Tech Publications Ltd., 2007; pp. $337-$ 340. 
10. Orizola, J.; Ríos-Silva, M.; Muñoz-Villagrán, C.; Vargas, E.; Vásquez, C.; Arenas, F. In vitro biosynthesis of $\mathrm{Ag}, \mathrm{Au}$ and Te-containing nanostructures by Exiguobacterium cell-free extracts. BMC Biotechnology 2020, 20, https://doi.org/10.1186/s12896-020-00625-y.

11. Dwyer, R.; Bruckard, W.J.; Rea, S.; Holmes, R.J. Bioflotation and bioflocculation review: microorganisms relevant for mineral beneficiation. Mineral Processing and Extractive Metallurgy 2012, 121, 65-71, https://doi.org/10.1179/1743285512Y.0000000005.

12. Pouran, H.M.; Banwart, S.A; Romero-Gonzalez, M. Characterizing the Cell Surface Properties of Hydrocarbon-Degrading Bacterial Strains, a Case Study. In: Handbook of Environmental Materials Management. Hussain, C.M. (ed.), Springer International Publishing AG, part of Springer Nature 2018; https://doi.org/10.1007/978-3-319-58538-3_131-2.

13. Liu, W.; Liu, W.; Wang, X.; Wei, D.; Wang, B. Utilization of novel surfactant N-dodecyl-isopropanol-amine as collector for efficient separation of quartz from hematite. Separation and Purification Technology 2016, 162, 188-194, https://doi.org/10.1016/j.seppur.2016.02.033.

14. Ran, J.; Qiu, X.; Hu, Z.; Liu, Q.; Song, B. Selective Flotation of Pyrite from Arsenopyrite by Low Temperature Oxygen Plasma Pre-Treatment. Minerals 2018, 8, https://doi.org/10.3390/min8120568.

15. Zhang, H.; Gao, Z.; Shi, M.; Fang, S. Soil Bacterial Diversity and Its Relationship with Soil $\mathrm{CO}_{2}$ and $\mathrm{Mineral}$ Composition: A Case Study of the Laiwu Experimental Site. Int J Environ Res Public Health 2020, 17, https://doi.org/10.3390/ijerph17165699.

16. Jiang, W.; Saxena, A.; Song, B.; Ward, B.B.; Beveridge, T.J.; Myneni, S.C.B. Elucidation of Functional Groups on Gram-Positive and Gram-Negative Bacterial Surfaces Using Infrared Spectroscopy. Langmuir 2004, 20, 11433-11442, https://doi.org/10.1021/la049043.

17. Schulz, B.; Sandmann, D.; Gilbricht, S. SEM-Based Automated Mineralogy and Its Application in Geo- and Material Sciences. Minerals 2020, 10, https://doi.org/10.3390/min10111004.

18. Hussein, F.B.; Venkiteshwaran, K.; Mayer, B.K. Cell surface-expression of the phosphate-binding protein PstS: System development, characterization, and evaluation for phosphorus removal and recovery. Journal of Environmental Sciences 2020, 92, 129-140, https://doi.org/10.1016/j.jes.2020.02.016.

19. Wang, S.; Liu, L.; Li, H.; Fang, F.; Yan, P.; Chen, Y.; Guo, J.; Ma, T.; Shen, Y. The branched chains and branching degree of exopolysaccharides affecting the stability of anammox granular sludge. Water Research 2020, 178, https://doi.org/10.1016/j.watres.2020.115818.

20. Zeng, Q.; Huang, L.; Ma, J.; Zhu, Z.; He, C.; Shi, Q.; Liu, W.; Wang, X.; Xia, Q.; Dong, H. Bio-reduction of ferrihydrite-montmorillonite-organic matter complexes: Effect of montmorillonite and fate of organic matter. Geochimica et Cosmochimica Acta 2020, 276, 327-344, https://doi.org/10.1016/j.gca.2020.03.011.

21. Zhao, Y.; Yan, H.; Zhou, J.; Tucker, M.E.; Han, M.; Zhao, H.; Mao, G.; Zhao, Y.; Han, Z. Bio-Precipitation of Calcium and Magnesium Ions through Extracellular and Intracellular Process Induced by Bacillus Licheniformis SRB2. Minerals 2019, 9, https://doi.org/10.3390/min9090526.

22. Ferreira, M.L.; Gerbino, E.; Cavallero, G.J.; Casabuono, A.C.; Couto, A.S.; Gomez-Zavaglia, A.; Ramirez, S.A.M.; Vullo, D.L. Infrared spectroscopy with multivariate analysis to interrogate the interaction of whole cells and secreted soluble exopolimeric substances of Pseudomonas veronii $2 \mathrm{E}$ with $\mathrm{Cd}(\mathrm{II}), \mathrm{Cu}(\mathrm{II})$ and Zn(II). Spectrochimica Acta Part A: Molecular and Biomolecular Spectroscopy 2020, 228, https://doi.org/ 10.1016/j.saa.2019.117820.

23. El-Taboni, F.; Caseley, E.; Katsikogianni, M.; Swanson, L.; Swift, T.; Romero-González, M.E. Fluorescence Spectroscopy Analysis of the Bacteria-Mineral Interface: Adsorption of Lipopolysaccharides to Silica and Alumina. Langmuir 2020, 36, 1623-1632, https://doi.org/10.1021/acs.langmuir.9b02158.

24. Ruan, Y.; Zhang, Z.; Luo, H.; Xiao, C.; Zhou, F.; Chi, R. Effects of Metal Ions on the Flotation of Apatite, Dolomite and Quartz. Minerals 2018, 8, 1-12, https://doi.org/10.3390/min8040141.

25. Wang, Y.; Wang, Y.; Xiao, W.; Wei, Y.; Li, S. Effect of $\mathrm{Cu}^{2+}$ on the Activation to Muscovite Using Electrochemical Pretreatment. Minerals 2020, 10, 1-13, https://doi.org/10.3390/min10030206.

26. Kondrat'ev, S.A.; Gavrilova, T.G. Physical Adsorption Mechanism in Terms of Sulphide Mineral Activation by Heavy Metal Ions. Journal of Mining Science 2018, 54, 466-478, https://doi.org/10.1134/ S1062739118033870.

27. Bogino, P.C.; Oliva, M.D.; Sorroche, F.G.; Giordano, W. The Role of Bacterial Biofilms and Surface Components in Plant-Bacterial Associations. International Journal of Molecular Sciences 2013, 14, 1538359; https://doi.org/10.3390/ijms140815838.

28. Sparks, D.J.; Romero-González, M.E.; El-Taboni, E.; Freeman, C.L.; Hall, S.A.; Kakonyi, G.; Swanson, L.; Banwart, S.A.; Harding, J.H. Adsorption of poly acrylic acid onto the surface of calcite: an experimental and simulation study. Physical Chemistry Chemical Physics 2015, 17, 27357-27365, https://doi.org/10.1039/C5CP00945F.

29. Sen, S. Gold Recovery by KC from grinding circuit of Bergama CIP plant. Rem Rev. Esc. Minas 2010, 63, 539-545, https://doi.org/10.1590/S0370-44672010000300017.

30. Garrett, T.R.; Bhakoo, M.; Zhang, Z. Bacterial adhesion and biofilms on surfaces. Progress in Natural Science 2008, 18, 1049-1056, https://doi.org/10.1016/j.pnsc.2008.04.001. 
31. Rampadarath, S.; Bandhoa, K.; Puchooa, D.; Jeewon, R.; Bal, S. Early bacterial biofilm colonizers in the coastal waters of Mauritius. Electronic Journal of Biotechnology 2017, 29, 13-21, https://doi.org/10.1016/ j.ejbt.2017.06.006.

32. Vásquez-Ponce, F.; Higuera-Llantén, S.; Pavlov, M.S.; Ramírez-Orellana, R.; Marshall, S.H.; OlivaresPacheco, J. Alginate overproduction and biofilm formation by psychrotolerant Pseudomonas mandelii depend on temperature in Antarctic marine sediments. Electronic Journal of Biotechnology 2017, 28, 27-34, https://doi.org/10.1016/j.ejbt.2017.05.001.

33. Govaert, M.; Smet, C.; Baka, M.; Ećimović, B.; Walsh, J.L.; Van Impe, J. Resistance of L. monocytogenes and S. Typhimurium towards Cold Atmospheric Plasma as Function of Biofilm Age. Applied Sciences 2018, 8, https://doi.org/10.3390/app8122702.

34. Achinas, S.; Charalampogiannis, N; Euverink, G.J.W. A Brief Recap of Microbial Adhesion and Biofilms. Appl. Sci. 2019, 9, https://doi.org/10.3390/app9142801. 